\title{
IMPACT OF EXCHANGE RATE AND CUSTOMS UNION ON TRADE BALANCE AT COMMODITY LEVEL OF TURKEY WITH EU (15)
}

\begin{abstract}
This paper investigates the short-run and long-run impact of exchange rate and customs union on the trade balance at commodity-group level of Turkey with EU (15). Bounds testing approach is employed where a new strategy in the model selection phase is adopted ensuring that optimal model is selected from those models satisfying both diagnostics and cointegration. Results indicate that in the short-run exchange rate matters in determination of trade balance of 13 commodity groups out of 21 and customs union in 8 cases. Pattern of response of trade balance to exchange rate does not suggest a J-curve effect in any of cases. As for the long-run effect, neither exchange rate nor customs union has a statistically significant effect on trade balance of any of commodity groups, suggesting that those significant short-run effects don't last into long-run.
\end{abstract}

Key words: J-curve, Customs Union, Bounds Testing Approach, Exchange Rate, Trade Balance

JEL Classification: C13, C22, F14, F31

\section{INTRODUCTION}

A country can devalue its currency and thus, by making its goods cheaper for foreigners and foreign goods more expensive for itself, improve its trade balance. Because of lags in response of trade flows to currency devaluation or depreciation, however, the abovementioned improvement in trade balance does not occur right away. It is therefore possible in the short-run that trade balance first deteriorates and then improves, resulting in $\mathrm{j}$-curve pattern.

Numerous studies have investigated empirically the impact of the exchange rate changes on the trade balance. In terms of the type of trade data utilized, these studies can be grouped into two major categories. The first category includes those studies that use trade data between one country and rest of the world, i.e. aggregate level data. Bahmani-Oskooee (1985), Noland (1989) and Gupta-Kapoor and Ramakrishnan (1999) can be cited as examples of aggregate level studies. This type of studies is criticized on grounds that they could be suffering from aggregation bias problem (the favorable effect on trade balance of depreciation with one partner could be offset by the unfavorable effect with another partner, resulting in a conclusion at the aggregate level that depreciation is ineffective) and as a result, bilateral level study, the second category, has emerged. Rose and Yelen (1989) is the first paper that initiated the research in bilateral direction. Other examples of bilateral level studies include Marwah and Klein (1996), Arora et al. (2003) and Bahmani-Oskooee and Ratha (2004).

\footnotetext{
* Corresponding Author: Department of Economics, Çankaya University, Öğretmenler Cad, No. 14, 06530 Balgat- Ankara, Turkey Tel: +90 312 2844500/303. Fax: +90 312 2864873. E-mail: myazici@cankaya.edu.tr.

** Department of Economics, Çankaya University, Öğretmenler Cad, No. 14, 06530 Balgat- Ankara, Turkey. E-mail: islammq@cankaya.edu.tr
} 
The most recent trend now is to disaggregate the trade data further, with the aim of avoiding possible aggregation bias problem, by considering trade balance at commodity or industry level in bilateral trade with a trading partner. The number of studies is few and includes Ardalani and Bahmani-Okooee (2007) and Bahmani-Okooee and Wang (2008).

The effect of exchange rate changes on Turkish trade balance has also been considered in the literature in a few papers. Brada et al. (1997) and Akbostanci (2004) have explored the exchange rate effect on the aggregate trade balance of Turkey. Brada et al. (1997) examines the responsiveness of aggregate trade balance of Turkey under two-sub periods and finds that trade balance was responsive to the exchange rate only in the sub-period during which tradeliberalizing economic reforms occurred. Akbostanci (2004) investigates the J-curve effect in Turkish data and finds no worsening of the aggregate trade balance in the short run but finds long-run improvement. Two papers by Halicioglu $(2007,2008)$ have investigated the issue on the bilateral basis. Halicioglu (2007) has explored the exchange rate effect on bilateral trade balance of Turkey with nine trading partners using Vector Error Correction method, and he later has extended the set of partners to include four more partners in Halicioglu (2008) but used bounds testing approach. Yazici (2008) examines and compares the response to exchange rate changes of trade balances of three Turkish sectors; agriculture, manufacturing and mining. Yazici and Klasra (2010) investigates, in the context of two sectors of Turkish economy that use imported inputs at different rates, how the response of trade balance to currency devaluation is affected by usage of imported inputs in production of exports.

Our study differs from these studies in that the set of the trading partners considered is not the same, none of them considers the effect of customs union agreement on trade balance $^{1}$, we further disaggregate trade data by considering commodity level trade between Turkey and EU(15) and even though Halicioglu (2008) has used the same approach, i.e. bounds testing approach, as explained below, unlike the previous literature, we select the optimal model from the subset of models that satisfy both diagnostics and cointegration.

The purpose of this paper is to examine the impact of currency depreciation and customs union on the commodity level trade balance of Turkey with an important trading partner, EU (15) countries, using bounds testing approach with the new strategy in the model selection phase we propose incorporated. EU (15) countries together constitute $49.7 \%$ of Turkey's total exports and $47.3 \%$ of Turkey's total imports over 1982-2001 period. Selecting EU (15) as the trading partner gives us in this setting the opportunity to investigate the effect on industry level trade balance of customs union that Turkey joined in January of 1996 with EU (15) countries. In classifying the commodity groups we have used Harmonized System (HS) and because data were available in digit 1 level we have employed data for commodity groups at digit 1 . There are 21 categories at this level and the list of name of corresponding commodity groups can be found in tables in this paper.

In the analysis in this paper we employ bounds testing approach developed by Peseran et al. (2001). The previous papers that have utilized this approach first select the optimum model using a certain model selection criterion such as Akaike Information Criterion (AIC) and then apply the cointegration and diagnostic tests to the selected model. Whatever results come up regarding the cointegration and diagnostics are reported in the end. We, however, first apply the cointegration and diagnostic tests to all possible combinations available given a maximum lag length and then determine those combinations that satisfy both the cointegration and the diagnostics. Finally, we apply model selection criterion to this set in order to come up with the optimal model for estimation. Unlike the previous work, our

\footnotetext{
${ }^{1}$ Effect of Turkey's customs union agreement with EU countries is investigated in the context of the effect on export and import demand functions in some papers, however. For example, Neyapti et al. (2007) shows that the customs union agreement has positively impacted exports and imports of Turkey and led to changes in the responsiveness of both exports and imports to underlying variables.
} 
approach ensures that the estimated optimum model is cointegrated and passes the diagnostics, thus enabling us to be sure that statistical inferences obtained from the estimated model using Ordinary Least Squares (OLS) are reliable.

The rest of the paper is organized as follows; in the following section the model employed in the estimation of the trade balance is set out, then the sources of data used in the estimation are described, the next section presents the empirical results obtained, and the last section contains the key findings and the concluding remarks.

\section{MODEL}

In modeling the trade balance, we closely follow the previous literature and specify it as a function of the real domestic income, the real foreign income, and the real exchange rate. The reduced form of trade balance equation for a given commodity group is expressed in a loglinear form in equation (1) as;

$$
\ln \mathrm{TB}_{\mathrm{i}, \mathrm{t}}=\mathrm{a}+\mathrm{b} \ln \mathrm{Y}_{\mathrm{TR}, \mathrm{t}}+\mathrm{c} \ln \mathrm{Y}_{\mathrm{EU}, \mathrm{t}}+\mathrm{d} \ln \mathrm{RER}_{\mathrm{t}}+\mathrm{eD}_{\mathrm{t}}+\varepsilon_{\mathrm{t}}
$$

Where $\mathrm{TB}_{\mathrm{i}, \mathrm{t}}$ is the trade balance of the commodity group i defined as the ratio of exports of the commodity group i of Turkey to EU(15) countries over Turkey's imports of the commodity group i from EU(15) countries, $\mathrm{Y}_{\mathrm{TR}}$ is Turkey's real income, $\mathrm{Y}_{\mathrm{EU}}$ is the real income of EU(15) countries constructed as the weighted average of real income of these countries where weights are assigned based on each country's share in Turkey's trade, RER is the real effective exchange rate between Turkey and currencies of EU(15) countries where nominal exchange rate is defined as the amount of Turkish Lira per trading partner's currency and $\mathrm{D}$ is the dummy variable for customs union, which takes on value 0 for quarters prior to the first quarter of 1996 and value 1 afterwards, given the fact that Turkey joined the Customs Union with EU in January of 1996.

As far as the expected signs of the variable coefficients are concerned, given the fact that an increase in real domestic income will stimulate the imports from abroad, the domestic income is expected to affect the trade balance negatively and therefore to have a negative coefficient. If, on the other hand, the increase in the domestic income results from an increase in the production of import-substitutes, the impact on the trade balance of the domestic income will be positive. By similar reasoning, an increase in the trading partner's real income will increase the exports and therefore the trade balance will improve. As in the case of domestic income, however, if the rise in the partner's income is due to the increase in the production of its import-substitutes, the effect of the trading partner's income on the trade balance will be negative. As for the effect of real exchange rate, given the fact that exchange rate is defined as the amount of domestic currency per foreign currency, a rise in the real exchange rate (depreciation) will lead to an improvement in trade balance by making the exports cheaper for foreigners and imports more expensive for that country, thus yielding a positive coefficient.

Equation (1) represents the long-run relationship among the variables. We, however, are not only interested in long-run effect on the trade balance of exchange rate changes but also in the short run impact. Therefore, we need to incorporate the short-run dynamics into Equation (1). We do this, following Peseran et al. (2001), by employing Autoregressive Distributed Lag Method (ARDL). In this case, Equation (1) is expressed in error-correction modeling format as follows; 


$$
\begin{aligned}
\Delta \ln \mathrm{TB}_{\mathrm{t}} & =\alpha+\sum_{\mathrm{j}=0}^{\mathrm{k}} \beta_{\mathrm{j}} \Delta \ln \mathrm{Y}_{\mathrm{TR}, \mathrm{t}-\mathrm{j}}+\sum_{\mathrm{j}=0}^{1} \gamma_{\mathrm{j}} \Delta \ln \mathrm{Y}_{\mathrm{EU}, \mathrm{t}-\mathrm{j}}+\sum_{\mathrm{j}=0}^{\mathrm{m}} \lambda_{\mathrm{j}} \Delta \ln \mathrm{RER}_{\mathrm{t}-\mathrm{j}}+\sum_{\mathrm{j}=1}^{\mathrm{n}} \theta_{\mathrm{j}} \Delta \ln \mathrm{TB}_{\mathrm{t}-\mathrm{j}} \\
& +\delta_{1} \ln \mathrm{Y}_{\mathrm{TR}, \mathrm{t}-1}+\delta_{2} \ln \mathrm{Y}_{\mathrm{EU}, \mathrm{t}-1}+\delta_{3} \ln \mathrm{RER}_{\mathrm{t}-1}+\delta_{4} \ln \mathrm{TB}_{\mathrm{t}-1}+\delta_{5} \mathrm{D}_{\mathrm{t}}+\mathrm{u}_{\mathrm{t}}
\end{aligned}
$$

In the bounds testing approach cointegration among the model variables is established using F-test. The null hypothesis of no cointegration $\left(\mathrm{H}_{0}: \delta_{1}=\delta_{2}=\delta_{3}=\delta_{4}=0\right)$ is tested against the alternative of cointegration $\left(\mathrm{H}_{1}: \delta_{1} \neq \delta_{2} \neq \delta_{3} \neq \delta_{4} \neq 0\right)$. Under the assumption of the null hypothesis, the distribution of F-statistic, however, is non-standard. Therefore, in testing the above hypothesis we use new critical values provided by Peseran et al. (2001). ${ }^{2}$ If the calculated F-statistic exceeds the upper bound critical value, we reject the null hypothesis and conclude that variables are cointegrated.

\section{DATA DESCRIPTION}

The frequency of the data is quarterly and it covers the period from 1982:I to 2001:IV. All data are indexed using 2000 quarterly average as the base and also they all are seasonally adjusted. We have obtained them from four sources; IMF-IFS Country Tables, Eurostat, Central Bank of Turkey and Statistics Office of Turkey. Data for export and import values are taken from Statistics Office of Turkey. Data for Gross Domestic Product (GDP), Industrial Production Index, GDP Deflator and Consumer Price Index (CPI), except for Greek CPI, are compiled from IMF-IFS Country tables. Source for CPI of Greece is Eurostat. Data for the bilateral nominal exchange rate between Turkish Lira and the currency of each of the EU (15) countries except for Finland, Greece, Ireland, Portugal and Spain are obtained from Central Bank of Turkey. The source for bilateral nominal exchange rates between Turkish Lira and the currency of Finland, Greece, Ireland, Portugal and Spain is Eurostat. Bilateral exchange rates between Turkish Lira and the currency of each of these countries are not, however, directly available in Eurostat. We have calculated them using the exchange rate between the currency of each country and ECU, the exchange rate between US dollar and ECU and the exchange rate between Turkish Lira and US dollar.

\section{ESTIMATION RESULTS}

In the present paper, we develop and follow a new strategy in selecting the model for the estimation. We believe that in order for inferences to be statistically reliable and therefore meaningful, the estimated model, from which test statistics for inferences are obtained, must well behave, i.e. it must satisfy basic assumptions of OLS. For this reason, given a maximum lag length, first those lag combinations that satisfy basic assumptions at a reasonably acceptable significance level (we set it at $10 \%$ ) are detected. And then for each of these selected lag combinations, using the F-test, it is checked whether there exists a cointegration among model variables or not. If there is at least one combination for which there exists cointegration, it is concluded that there is a long run relationship among the model variables.

Once cointegration is established according to above procedure, the next step is to estimate the error correction model in (2). The question of which lag combination to use for estimation, i.e. optimal model, however, has to be settled. Here we employ AIC. The optimal

\footnotetext{
${ }^{2}$ The upper bound critical value for the F-statistic at $10 \%$ significance level is 3.77, taken from Peseran et al. (2001) (Table CI, Case III, p.300).
} 
model is selected by applying AIC to the set of those lag combinations that both satisfy diagnostics and indicate a cointegration.

An algorithm developed by the second author is used to settle the issues mentioned above. First, the maximum lag length on each first-differenced variable in equation (2) is set as 10 . The model corresponding to each possible lag combination has been estimated and then those combinations that satisfy the diagnostic tests of normality, no serial correlation and no heterescodasticty at least at $10 \%$ level have been selected. For each of these selected combinations, it is checked whether there exists a cointegration or not. In case no cointegration is established for a combination, that combination is discarded. Then, in order to determine the optimal model, AIC has been applied to the set of those lag combinations that satisfy diagnostic tests at least at $10 \%$ level and at the same time indicate a cointegration. Having followed this procedure, we have come up with the optimal lag combinations reported in Table $1 .^{3}$

Table 1: Optimal Lag Orders: Our Strategy vs. Previous Literature

\begin{tabular}{|c|c|c|c|c|c|c|}
\hline \multirow[t]{2}{*}{ Commodity Groups } & \multirow[t]{2}{*}{$\begin{array}{c}\text { Lag Order with Our } \\
\text { Strategy }\end{array}$} & \multicolumn{5}{|c|}{$\begin{array}{l}\text { Lag order and Diagnostic Results with } \\
\text { Previous Literature }\end{array}$} \\
\hline & & Lag Order & $\mathrm{N}$ & $S$ & $\mathrm{H}$ & $\mathrm{C}$ \\
\hline Animals \& Animal Products & $8,3,7,5$ & $10,6,9,6$ & $\sqrt{ }$ & $x$ & $\sqrt{ }$ & $\sqrt{ }$ \\
\hline Vegetable Products & $4,6,0,7$ & $1,6,3,7$ & $\sqrt{ }$ & $x$ & $x$ & $\sqrt{ }$ \\
\hline Animal or Vegetable Fats & $2,10,10,3$ & $10,10,10,10$ & $\sqrt{ }$ & $\times$ & $\times$ & $\sqrt{ }$ \\
\hline Prepared Food Stuffs & $4,1,1,0$ & $4,1,1,0$ & $x$ & $\sqrt{ }$ & $\sqrt{ }$ & $\sqrt{ }$ \\
\hline Mineral Products & $4,10,9,4$ & $5,10,9,4$ & $\sqrt{ }$ & $x$ & $\sqrt{ }$ & $\sqrt{ }$ \\
\hline Chemical Products & $8,4,0,0$ & $7,10,10,9$ & $\sqrt{ }$ & $\sqrt{ }$ & $\sqrt{ }$ & $x$ \\
\hline Plastic \& Rubber & $8,4,7,7$ & $8,7,5,9$ & $\sqrt{ }$ & $\times$ & $\sqrt{ }$ & $\sqrt{ }$ \\
\hline Hides \& Skins & $7,10,7,2$ & $8,8,10,10$ & $\sqrt{ }$ & $x$ & $\sqrt{ }$ & $\sqrt{ }$ \\
\hline Wood \& Wood Products & $3,0,7,1$ & $4,10,9,6$ & $\sqrt{ }$ & $\times$ & $\sqrt{ }$ & $\sqrt{ }$ \\
\hline Wood Pulp Products & $10,5,10,10$ & $10,5,10,10$ & $\sqrt{ }$ & $x$ & $\sqrt{ }$ & $\sqrt{ }$ \\
\hline Textiles \& Textile Articles & $5,3,5,6$ & $5,3,5,6$ & $\sqrt{ }$ & $\sqrt{ }$ & $\sqrt{ }$ & $\sqrt{ }$ \\
\hline Footwear, Headgear & $1,1,9,4$ & $8,10,10,10$ & $\sqrt{ }$ & $x$ & $\sqrt{ }$ & $\sqrt{ }$ \\
\hline $\begin{array}{l}\text { Articles of Stone, Plaster, Cement, } \\
\text { Asbestos }\end{array}$ & $10,4,3,0$ & $10,10,7,10$ & $\sqrt{ }$ & $\times$ & $\sqrt{ }$ & $\sqrt{ }$ \\
\hline $\begin{array}{l}\text { Pearls, Precious or Semi-Precious } \\
\text { Stones, Metals }\end{array}$ & $8,6,9,2$ & $8,6,9,2$ & $\sqrt{ }$ & $\sqrt{ }$ & $\sqrt{ }$ & $x$ \\
\hline Base Metals \& Articles Thereof & $4,6,8,0$ & $4,6,8,0$ & $\sqrt{ }$ & $\sqrt{ }$ & $\sqrt{ }$ & $\sqrt{ }$ \\
\hline Machinery \& Mechanical Appliances & $10,0,5,0$ & $10,0,5,0$ & $\sqrt{ }$ & $x$ & $\times$ & $\sqrt{ }$ \\
\hline Transportation Equipments & $1,5,0,6$ & $7,9,10,6$ & $\sqrt{ }$ & $x$ & $\sqrt{ }$ & $\sqrt{ }$ \\
\hline Instruments - Measuring, Musical & $9,0,3,10$ & $9,0,3,10$ & $x$ & $\times$ & $x$ & $\sqrt{ }$ \\
\hline Arms \& Ammunition & $2,7,3,0$ & $10,10,10,10$ & $x$ & $x$ & $\sqrt{ }$ & $\sqrt{ }$ \\
\hline Miscellaneous & $9,2,9,10$ & $9,2,9,10$ & $\sqrt{ }$ & $\sqrt{ }$ & $x$ & $x$ \\
\hline Works of Art & $1,6,1,0$ & $6,7,10,9$ & $\sqrt{ }$ & $x$ & $\sqrt{ }$ & $\sqrt{ }$ \\
\hline
\end{tabular}

\footnotetext{
${ }^{3}$ In Table 1 the lag combinations picked up when the strategy of previous literature is adopted are also reported. When compared with our strategy, in 8 cases out of 21 lag combinations selected coincide. Table 1 also contains diagnostic test results of strategy of previous literature. We observe that normality assumption fails in 3 cases, no serial correlation assumption in 15 cases, no heteroscedasticity assumption in 5 cases and cointegration in 3 cases.
} 
Having determined the optimal combinations, we have then proceeded to estimate the model in Equation (2) corresponding to optimal lag combinations reported in Table 1 for the commodity groups included based on the quarterly data covering the period of 1982:I 2001:IV. Short-run impact of the exchange rate on the commodity trade balance is inferred from the coefficients of the first-differenced exchange rate variable. To assess the short-run effect of the exchange rate, estimates of those coefficients are reported in Table $2 .^{4}$

Note that in commodity groups of Animal or Vegetable Fats, Prepared Food Stuffs, Chemical Products, Footwear Headgear, Articles of Stone Plaster Cement Asbestos, Pearls Precious or Semi-Precious Stones Metals, Machinery \& Mechanical Appliances and Arms \& Ammunition, exchange rate variable has no significant coefficient. This implies that the real depreciation of Turkish Lira has no short-run significant effect in these commodities. In all other commodity groups at least one of the coefficients of the exchange rate variable is significant, meaning that the exchange rate matters in the short run in these 13 industries. As a short-run phenomenon, we are particularly interested whether or not J-curve effect exists in Turkey's commodity-level trade with EU (15) countries. Given the fact that the exchange rate is defined in such a way that a rise in the exchange rate represents the depreciation or devaluation of Turkish Lira, J-curve effect will be observed if the coefficient of the firstdifferenced exchange rate variable has first negative values and then positive ones. Looking at the Table 1 reveals that in none of 21 commodity groups such a pattern of signs of exchange rate coefficients is observed. Taking into account this fact, we can conclude that in Turkey's trade with EU (15) countries at industry level no evidence is found supporting the J-curve phenomenon.

\footnotetext{
${ }^{4}$ Because the focus of paper is on impacts of exchange rate and customs union agreement, to conserve space, only coefficient estimates for these two variables are reported in Table 2.
} 


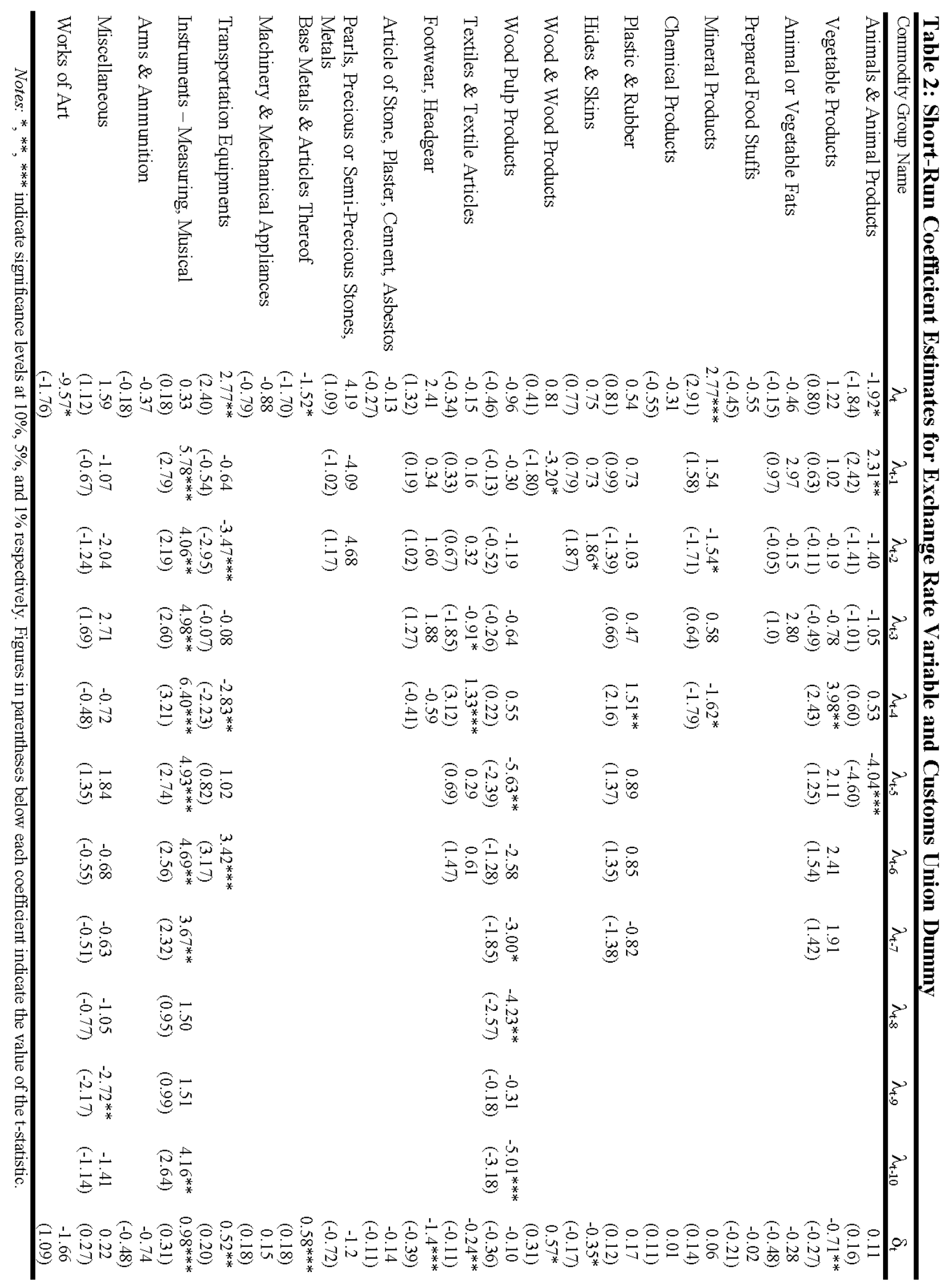


Also reported in Table 2 are short-run coefficient estimates for customs union dummy. We observe that customs union agreement of Turkey with EU (15) countries has significant effect in the short run in industries of Vegetable Products, Hides \& Skins, Wood \& Wood Products, Textiles \& Textile Articles, Footwear Headgear, Base Metals \& Articles Thereof, Transportation Equipments and Instruments - Measuring Musical. The commodity groups whose trade balances have been affected positively by customs union are Wood \& Wood Products, Base Metals \& Articles Thereof, Transportation Equipments and Instruments Measuring Musical. Customs union agreement has negatively affected in the short-run the trade balances of Vegetable Products, Hides \& Skins, Textiles \& Textile Articles and Footwear Headgear.

As for the long-run effect, long-run estimates are fully reported in Table 3. We observe that real exchange rate variable does not have any statistically significant coefficient in any of 21 industries. This finding implies that changes in the real exchange rate do not affect Turkey's commodity trade balance in the long run with EU (15) countries. In other words exchange rate variable is not a significant determinant in Turkey's commodity trade balance with EU (15). This suggests that the exchange rate policy can't be used to influence trade balance in a favorable way. As far as the effect of customs union is concerned, this agreement doesn't have a long-run significant effect on trade balances of any of industries, either. This implies that Turkey's participation in the customs union has not significantly affected its commodity trade balance, at least during the study period. This result isn't surprising and can be explained in light of two facts. First, in 1970 with a protocol to the Treaty of Ankara signed in 1963, Turkish goods were allowed to enter European Union free of any restrictions, long time before customs union agreement in 1996. For this reason Turkish exports should not be expected to respond significantly to the joining of customs union in 1996. 
Table 3: Long-Run Coefficient Estimates

\begin{tabular}{|c|c|c|c|c|c|}
\hline Commodity Group Name & Constant & $\ln Y_{\mathrm{TR}}$ & $\ln Y_{\mathrm{EU}(15)}$ & ln RER & $\mathrm{D}$ \\
\hline Animals \& Animal Products & $\begin{array}{c}-0.35 \\
(-1.32)\end{array}$ & $\begin{array}{c}-1.64 * * * \\
(-5.27)\end{array}$ & $\begin{array}{c}-0.02 \\
(-0.02)\end{array}$ & $\begin{array}{c}-0.40 \\
(-0.19)\end{array}$ & $\begin{array}{c}0.11 \\
(0.19)\end{array}$ \\
\hline Vegetable Products & $\begin{array}{c}2.90 * * * \\
(3.51)\end{array}$ & $\begin{array}{c}-2.49 * * * \\
(-2.93)\end{array}$ & $\begin{array}{l}7.63 * * \\
(2.27)\end{array}$ & $\begin{array}{c}-0.21 \\
(-0.05)\end{array}$ & $\begin{array}{c}-0.89 \\
(-0.90)\end{array}$ \\
\hline Animal or Vegetable Fats & $\begin{array}{c}0.27 \\
(0.34)\end{array}$ & $\begin{array}{l}-5.49 * \\
(-1.72)\end{array}$ & $\begin{array}{l}18.32 \\
(1.54)\end{array}$ & $\begin{array}{c}0.83 \\
(0.08)\end{array}$ & $\begin{array}{c}-0.33 \\
(-0.18)\end{array}$ \\
\hline Prepared Food Stuffs & $\begin{array}{c}0.99 * * * \\
(3.80)\end{array}$ & $\begin{array}{c}-0.24 \\
(-1.04)\end{array}$ & $\begin{array}{c}-2.69 \\
(-1.58)\end{array}$ & $\begin{array}{c}-0.12 \\
(-0.05)\end{array}$ & $\begin{array}{c}-0.03 \\
(-0.05)\end{array}$ \\
\hline Mineral Products & $\begin{array}{c}-0.45 \\
(-1.50)\end{array}$ & $\begin{array}{c}-3.83 * * * \\
(-5.38)\end{array}$ & $\begin{array}{c}1.61 \\
(0.85)\end{array}$ & $\begin{array}{l}1.24 \\
(0.41)\end{array}$ & $\begin{array}{c}0.07 \\
(0.12)\end{array}$ \\
\hline Chemical Products & $\begin{array}{c}-2.57 * * * \\
(-2.73)\end{array}$ & $\begin{array}{l}1.07 * * \\
(2.14)\end{array}$ & $\begin{array}{l}-3.93^{*} \\
(-1.82)\end{array}$ & $\begin{array}{c}-0.26 \\
(-0.09)\end{array}$ & $\begin{array}{c}0.01 \\
(0.01)\end{array}$ \\
\hline Plastic \& Rubber & $\begin{array}{l}-1.91 * \\
(-2.01)\end{array}$ & $\begin{array}{c}0.38 \\
(0.65)\end{array}$ & $\begin{array}{c}-3.50 \\
(-1.16)\end{array}$ & $\begin{array}{c}-0.60 \\
(-0.13)\end{array}$ & $\begin{array}{c}0.52 \\
(0.41)\end{array}$ \\
\hline Hides \& Skins & $\begin{array}{c}0.26 \\
(1.45)\end{array}$ & $\begin{array}{c}2.02 * * * \\
(3.43)\end{array}$ & $\begin{array}{c}-10.4^{* * *} \\
(-5.11)\end{array}$ & $\begin{array}{c}-2.37 \\
(-0.80)\end{array}$ & $\begin{array}{c}-0.36 \\
(-0.52)\end{array}$ \\
\hline Wood \& Wood Products & $\begin{array}{c}-2.07 \\
(-1.57)\end{array}$ & $\begin{array}{c}-7.80 * * \\
(-2.63)\end{array}$ & $\begin{array}{c}9.82 * * \\
(2.64)\end{array}$ & $\begin{array}{c}0.60 \\
(0.15)\end{array}$ & $\begin{array}{c}0.68 \\
(0.61)\end{array}$ \\
\hline Wood Pulp Products & $\begin{array}{c}-2.13 \\
(-1.19)\end{array}$ & $\begin{array}{c}-9.55^{* *} \\
(-2.64)\end{array}$ & $\begin{array}{c}17.03^{* *} \\
(2.58)\end{array}$ & $\begin{array}{c}1.61 \\
(0.36)\end{array}$ & $\begin{array}{c}-0.01 \\
(-0.01)\end{array}$ \\
\hline Textiles \& Textile Articles & $\begin{array}{c}1.75^{* * *} \\
(5.75)\end{array}$ & $\begin{array}{c}0.17 \\
(0.57)\end{array}$ & $\begin{array}{c}-2.36 * * * \\
(-2.78)\end{array}$ & $\begin{array}{c}-0.46 \\
(-0.36)\end{array}$ & $\begin{array}{c}-0.34 \\
(-0.80)\end{array}$ \\
\hline Footwear, Headgear & $\begin{array}{c}-0.06 \\
(-0.13)\end{array}$ & $\begin{array}{c}-1.80 * * * \\
(-3.25)\end{array}$ & $\begin{array}{c}2.67 \\
(1.40)\end{array}$ & $\begin{array}{c}0.49 \\
(0.16)\end{array}$ & $\begin{array}{c}-1.44 \\
(-1.37)\end{array}$ \\
\hline $\begin{array}{l}\text { Articles of Stone, Plaster, Cement, } \\
\text { Asbestos }\end{array}$ & $\begin{array}{c}0.75^{* * *} \\
(4.36)\end{array}$ & $\begin{array}{c}-2.54 * * * \\
(-9.48)\end{array}$ & $\begin{array}{c}4.82 * * * \\
(4.61)\end{array}$ & $\begin{array}{c}-0.78 \\
(-0.47)\end{array}$ & $\begin{array}{c}-0.19 \\
(-0.56)\end{array}$ \\
\hline $\begin{array}{l}\text { Pearls, Precious or Semi-Precious } \\
\text { Stones, Metals }\end{array}$ & $\begin{array}{l}2.02^{* *} \\
(2.12\end{array}$ & $\begin{array}{l}-4.74 \\
(-1.26)\end{array}$ & $\begin{array}{l}24.65 \\
(1.12)\end{array}$ & $\begin{array}{c}3.89 \\
(0.27)\end{array}$ & $\begin{array}{l}-1.43 \\
(-0.34)\end{array}$ \\
\hline Base Metals \& Articles Thereof & $\begin{array}{l}-1.76 \\
(-1.20)\end{array}$ & $\begin{array}{c}-0.79 \\
(-1.32)\end{array}$ & $\begin{array}{l}-2.93 \\
(-1.14)\end{array}$ & $\begin{array}{c}-0.61 \\
(-0.14)\end{array}$ & $\begin{array}{c}1.38 \\
(1.27)\end{array}$ \\
\hline $\begin{array}{l}\text { Machinery \& Mechanical } \\
\text { Appliances }\end{array}$ & $\begin{array}{l}-1.51^{* *} \\
(-2.30)\end{array}$ & $\begin{array}{c}-2.99 * * \\
(-5.13)\end{array}$ & $\begin{array}{l}5.71 * * \\
(4.21)\end{array}$ & $\begin{array}{l}-0.20 \\
(-0.11)\end{array}$ & $\begin{array}{c}0.17 \\
(0.32)\end{array}$ \\
\hline Transportation Equipments & $\begin{array}{l}-1.88 * * \\
(-2.35)\end{array}$ & $\begin{array}{c}-5.60 * * * \\
(-4.21)\end{array}$ & $\begin{array}{c}10.45^{* * *} \\
(4.14)\end{array}$ & $\begin{array}{c}1.44 \\
(0.43)\end{array}$ & $\begin{array}{c}0.60 \\
(0.74)\end{array}$ \\
\hline Instruments - Measuring, Musical & $\begin{array}{l}-3.36^{* *} \\
(-2.22)\end{array}$ & $\begin{array}{c}2.88 * * * \\
(3.86)\end{array}$ & $\begin{array}{l}-5.02 * * \\
(-2.03)\end{array}$ & $\begin{array}{l}-2.37 \\
(-0.80)\end{array}$ & $\begin{array}{c}0.86 \\
(0.73)\end{array}$ \\
\hline Arms \& Ammunition & $\begin{array}{l}-1.99 \\
(-1.29)\end{array}$ & $\begin{array}{l}-8.17^{*} \\
(-1.95)\end{array}$ & $\begin{array}{l}10.09 * \\
(1.74)\end{array}$ & $\begin{array}{c}0.11 \\
(0.02)\end{array}$ & $\begin{array}{c}-0.80 \\
(-0.70)\end{array}$ \\
\hline Miscellaneous & $\begin{array}{l}-1.42 \\
(-1.41)\end{array}$ & $\begin{array}{c}-2.48 * * * \\
(-2.96)\end{array}$ & $\begin{array}{c}1.65 \\
(0.48)\end{array}$ & $\begin{array}{c}0.32 \\
(0.06)\end{array}$ & $\begin{array}{c}0.33 \\
(0.25)\end{array}$ \\
\hline Works of Art & $\begin{array}{c}-2.57 \\
(-0.63)\end{array}$ & $\begin{array}{l}-14.17 \\
(-0.83)\end{array}$ & $\begin{array}{l}32.90 \\
(0.84)\end{array}$ & $\begin{array}{c}5.74 \\
(0.43)\end{array}$ & $\begin{array}{c}-1.84 \\
(-0.56)\end{array}$ \\
\hline
\end{tabular}

Notes: $*, * *, * * *$ indicate significance levels at $10 \%, 5 \%$, and $1 \%$ respectively. Figures in parentheses below each coefficient indicate the value of the t-statistic.

Second, Turkey’s imports consist mainly inputs. ${ }^{5}$ To continue to grow, Turkey has to import those inputs. This nature of Turkey's import structure implies that Turkey has to continue importing regardless of a customs union agreement. Therefore, imports should not be expected to respond significantly to the customs union, either. As a result of these two reasons, customs union should not significantly affect Turkey's trade balance.

Even though real exchange rate is not a significant determinant for trade balance of any of commodity groups in the long run, other determinants, namely Turkish real income and EU(15) real income, are significant. Real domestic income is a significant long-run

\footnotetext{
${ }^{5}$ According to data from Statistics Office of Turkey (www.tuik.gov.tr), in 2008 imports of raw materials, intermediate goods and investment goods (179.8 billion dollars) constituted 89\% of total imports of Turkey (201.9 billion dollars).
} 
determinant of trade balances of 15 industries. EU(15) real income is a significant determinant in the long-run of trade balances of 8 industries. Overall we can say that Turkish real income and EU(15) real income are driving forces behind trade balances of Turkish industries. In other words, growths of Turkish economy and EU(15) economies are main factors that determine how trade balances of Turkish industries behave in the long-run.

\section{CONCLUSION}

This paper has examined the effect of exchange rate and customs union in the short run as well as in the long run on commodity-level trade balance of Turkey with EU (15) countries based on the quarterly data over 1982:I-2001-IV period. Previous studies have investigated the impact of exchange rate on trade balance either at the aggregate level or bilateral level. Results obtained from both types of studies are mixed and such a result is attributed to aggregation bias problem. Realizing this problem, with the hope of reducing the bias a new body of research has emerged, namely the bilateral analysis at the commodity level. One exception is the case of Turkey. The present paper fills in this vacuum in the literature by considering the bilateral trade of Turkey with EU (15) at commodity level. Given the fact that the trading partner selected is EU (15) and that Turkey joined the customs union with these countries in 1996, this paper has also explored the effect on the trade balance of the customs union agreement. Another contribution of this paper, as explained in detail earlier, is that a new strategy in model selection phase is adopted and unlike the previous literature optimal model for the estimation is selected, from the set of those combinations that satisfy both diagnostic requirements and the cointegration, ensuring that inferences obtained from the estimation are statistically reliable.

As far as the short-run impacts of the exchange rate and customs union are concerned, exchange rate changes and customs union have significantly affected certain commodity groups in the short-run. No J-curve effect is observed in any of industries. As for the long-run effect, our results indicate that real depreciation of Turkish Lira and customs union have not significantly affected trade balance of any of industries. This finding suggests that exchange rate policy can't be used as a policy tool to improve the trade balance. Factors that are significant determinants of trade balances of Turkish industries in the long-run are found to be Turkish and EU (15) real incomes.

\section{REFERENCES}

Akbostanci, E., (2004), "Dynamics of Trade Balance: The Turkish J-Curve”, Emerging Markets Finance and Trade, 40: 57-73.

Ardalani, Zohre and M. Bahmani-Oskooee, (2007), "Is There a J-curve at the Industry Level?”, Economics Bulletin, 6:1-12.

Arora, A., M. Bahmani-Oskooee, and G. Goswami, (2003), "Bilateral J-curve between India and Her Trading Partners”, Applied Economics, 35: 1037-1041.

Bahmani-Oskooee, M., (1985), "Devaluation and the J-Curve: Some Evidence from LDCs", Review of Economics and Statistics, 67: 500-504.

Bahmani-Oskooee, M., and A. Ratha, (2004), “The J-Curve Dynamics of US Bilateral Trade”, Journal of Economics and Finance, 28: 32-38.

Bahmani-Oskooee, M. and Y. Wang, (2008), "The J-curve: Evidence from Commodity Trade between US and China”, Applied Economics, iFirst:1-13

Brada, J. C., A. M. Kutan, and S. Zhou, (1997), "The Exchange Rate and the Balance of Trade: The Turkish Experience”, Journal of Development Studies, 33: 675-692. 
Gupta-Kapoor, A., and U. Ramakrishnan, (1999), "Is There a J-Curve? A New Estimation for Japan”, International Economic Journal, 13: 71-79.

Halicioglu, F., (2007), "The J-Curve Dynamics of Turkish Bilateral Trade: A Cointegration Approach.”, Journal of Economic Studies, 34: 103-119.

Halicioglu, F., (2008), “The Bilateral J-Curve: Turkey vs. her 13 Trading Partners”, Journal of Asian Studies, 19: 236-243.

Marwah, K., and L. R. Klein, (1996), “Estimation of J-Curve: United States and Canada”, Canadian Journal of Economics, 29: 523-539.

Neyapti, B., Taskin, F. and Ungor, M., (2007), "Has European Customs Union Agreement Really Affected Turkey’s Trade?”, Applied Economics 39: 2121-2132.

Noland, M., (1989), “Japanese Trade Elasticities and J-Curve”, Review of Economics and Statistics, 71: 175-179.

Peseran, M. H., Y. Shin, and R. J. Smith, (2001), "Bounds Testing Approaches to the Analysis of Level Relationships", Journal of Applied Econometrics, 16: 289-326.

Rose, A. K., and J. L. Yellen, (1989), “Is There a J-Curve?”, Journal of Monetary Economics, 24: 53-68.

Yazici, M. and M. A. Klasra, (2010), "Import-Content of Exports and J-curve Effect", Applied Economics, 42: 769-776.

Yazici, M., (2008), "The Exchange Rate and the Trade Balances of Turkish Agriculture, Manufacturing and Mining”, Quality \& Quantity, 42: 45-52.

\section{UČINAK TEČAJA I CARINSKE UNIJE NA TRGOVINSKU BILANCU SIROVINA TURSKE S EU (15)}

\section{SAŽETAK}

Ovaj rad proučava kratkoročni i dugoročni učinak tečaja i carinske unije na trgovinsku bilancu sirovina Turske s EU (15). Koristi se pristup graničnog testa gdje se u fazi odabira modela koristi nova strategija koja osigurava odabir optimalnog modela između onih koji udovoljavaju kako dijagnostici tako $i$ kointegraciji. Rezultati ukazuju da, kratkoročno gledano, tečaj ima utjecaja na određivanje trgovinske bilance 13 grupa sirovina od 21, dok carinska unija utječe u 8 slučajeva. Uzorak odgovora trgovinske bilance na tečaj ne ukazuje na efekt J-krivulje ni u jednom slučaju. Što se tiče dugoročnog učinka, niti tečaj niti carinska unija nemaju statistički značajan učinak na trgovinsku bilancu bilo koje grupe sirovina, ukazujući na to da viđeni kratkoročni učinci ne prelaze u dugoročne.

Ključne riječi: J-krivulja, carinska unija, granični test, tečaj, trgovinska bilanca JEL klasifikacija: C13, C22, F14, F31 